\title{
Art and Morality
}

\author{
Tolstoy vs. Leontiev
}

\author{
Konstantin Antonov \\ Faculty of Theology \\ Saint-Tikhon's Orthodox University \\ Moscow, Russia \\ E-mail: konstanturg@yandex.ru
}

\author{
Alexey Chernyak \\ Faculty of Humanities and Social Sciences \\ Peoples' Friendship University of Russia \\ Miklukho-Maklay str., 10/2, Moscow, Russia, 117198 \\ E-mail: abishot2100@yandex.ru
}

\begin{abstract}
Art influences people in different ways; in particular, it may cause certain moral effects. Is it right to say that the purpose of art is to produce certain moral impact on people or that its values depend essentially on how moral it is? The following paper observes aesthetic views of two famous Russian philosophers, Leo Tolstoy and Konstantin Leontiev, and, in particular, their conceptions of the relation between art and morality. It argues that although their accounts are in many respects antagonistic both thinkers agree that there is a profound link between artistic and moral values.
\end{abstract}

Keywords —art; morality; communication; feeling; infection; sincerity; religious consciousness

\section{INTRODUCTION: ART AND MORAL CONTENT}

Art may change people's behavior, and it may have a moral influence on it, intentionally or not. At least a few pieces of art do this, and some are created to illustrate certain moral values. ${ }^{1}$ But there are other recognized pieces of art that seem to convey no information about moral values and were not created to illustrate any of them. Most abstract or decorative art displays no essential connection with morality, and realistic art, which purports only to reflect reality with maximal accuracy, does not need to care about moral effects of its works. On the contrary, the very choice of a subject of the realistic representation may be and often is morally motivated.

Sometimes artworks that are recognized as intentionally avoiding moralizing as well as expressing any other nonaesthetic $^{2}$ are called pure art, but this classification presupposes that art is not determined by any non-aesthetic value, moral in particular. Meanwhile philosophers also disagree about both: the proper purpose or essence of art and its relation to morality. In particular, not every theory of art singles out beauty as its main purpose. Aristotle, and especially Plato, sees in art an instrument of education in the first place [1. Ch. 6, 9, 11, 13, 14] [11. PP. 377b - 398b]. For Plato art has value only as far as it serves the public good [11. P. 425a]. On the other hand, according to Kant the issues of aesthetics and ethics are essentially different. Moral maxims express categorical imperatives that guide individuals in

\footnotetext{
${ }^{1}$ See, e.g., Allegories of Good and Bad Ruling by Ambrogio Lorenzetti from Palazzo del Populo in Siena.

${ }^{2}$ What makes a value aesthetic is itself a matter of intensive philosophical debates though.
}

moral actions to the good itself independently on practical values of these actions [5. P. 254]; meanwhile aesthetic judgments are subjective universal expressions of taste based on a feeling of pleasure that serves no other interest (including moral one) [6. P. 240].

Some philosophers think that definition of art is as such a matter of consensus: that, in brief, critiques, gallerists and other art experts decide what art is and what it is not. From this point of view, art is a specific social institute that rather creates certain aesthetic values than is based upon them. ${ }^{3}$ There are recognized artworks representing something awful or even disgusting. Such works might be alternatively interpreted as attempts to create new standards of beauty or as a counterfeit art, but, obviously, if they have any artistic value, it disagrees with the common idea of beauty. Nevertheless, they still may have distinctive moral meanings.

One of those who consider moral contents as a necessary condition of art was great Russian thinker and writer: Leo Tolstoy. His idea of art seems very rigorous but still preserves its attraction. His main work on the subject is "What is art?" [13]. Traditional perception of the idea of the connection between art and morality expressed in it consists in the claim that Tolstoy reduces aesthetical value to ethical [12]. How much of this is true?

\section{TOLSTOY'S IDEA OF ART}

According to Tolstoy, art is a big organized sphere of human activity involving not only artists, writers, composers etc., but also dealers, workers, engineers, producers, peasants and so on. Art generates not only artworks but also very specific relations between people that are opposite to those of brotherhood and mutual love. 4 From this, Tolstoy concludes that professional art distorts human nature, and

\footnotetext{
3 Thus, according to Marxists art expresses interests of classes dominant in certain historical period. In this role art may contradict as to the public morality so to the mainstream aesthetic preferences.

${ }^{4}$ Easy to see that Tolstoy is far from considering human beings as natural self-interested egoists, and close to the anthropological ideas of Russo and Kant. The very reason for the Tolstoy's question seems to be ethical; for it is important to see something bad or improper in a distortion of a human nature, and breaking with love and brotherhood to call it a sacrifice. Also it is easy to note that art is far not the only such "distorting" sphere of human activity: compare the relations in sport or busyness.
} 
asks: is it justified to sacrifice your own nature for the sake of art? What is so important about art?

Answering these questions he analyses the concept of art, and notices that, for the majority of people, art is tightly connected to beauty. But what is beauty? Tolstoy finds two main definitions in the history of aesthetical thought. The first considers beauty as an idea that guides people toward God after all. The second reduces beauty to what pleases. The main shortcoming of both accounts he sees is their vagueness. The first definition makes beauty very wide concept including many categories category such as philosophy, religion and life itself. The second definition also allows too many things to be sources of beauty, such as, e.g., food and drink.5 He denies the definition of beauty as a matter of taste because it leads to the subjectivism in the theory of art: "...once recognizing certain kind of works good because we like them" we create "such theory of art that all works liked by a certain circle of people would become part of this theory" [13. P. 79]. Therefore, Tolstoy concludes that the notion of beauty contributes nothing to the definition of art and rather was developed to vindicate the existence of art and sacrifices that it requires. He writes ironically: "The aim of art is beauty, and what is beauty is known from pleasure which it gives", therefore "the pleasure from art is good and important. The pleasure from art is good because it is pleasure" [13. P. 83].

In order to give a more adequate definition, Tolstoy proposes to quit looking at art as a source of pleasure. He claims that it is rather a means of communication between people: "Each work of art makes a perceiver engage in certain communication with the one who produced or produces art, and with all those who have simultaneously, had before or will have after him the same artistic experience" [13. PP. 84-85]. Art acts in this respect in the same way as words do, but words communicate people's thoughts while art communicates their feelings. The activity of art is based on the ability of people to feel what other people feel when they hear or see expressions of such feeling. Tolstoy calls this effect an "infection" by feelings of someone else. But infection as such isn't yet art: art begins when people intentionally cause in themselves certain feelings and express them by signs conceivable by other people [13. PP. 85-86].6

From this perspective it seems impossible to create artwork without passion: one needs "to cause in oneself feeling once experienced and... by movements, lines, colors, sounds, images expressed by words, report this feeling so as to make others experience it" [13. P. 87]. And an artistic experience, i.e. an infection, is produced only when the author himself has experienced the feeling which he tries to communicate, not when he communicates someone else's feeling [13. P. 87].

\footnotetext{
${ }^{5}$ But note that according to Kant pleasures from food and drink are not inspired by beauty [5. PP. 210-211].

${ }^{6}$ Notice that although this account resembles aesthetic idealism according to which art is a mean of self-expression of an artist, the requirement of infectiousness makes it different (another distinctive feature of this account is the requirement of conceivability of art to be stated below).
}

Therefore, Tolstoy proposes a clear criterion of art evaluation according to which a work is not a genuine piece of art unless it infects its perceivers. How many of them must be infected or how often the infection must take place may be then seen as variables making a work more or less artistic in comparison with other works. It may be supposed though that the same infectious effects or something close to them may be produced also by perceptions of works whose authors didn't experience or did not experience the communicated feelings fully enough if those works are sufficiently attractive or interesting for their perceivers. For example a work may cause a sense of nostalgia due to resemblances with something pleasant preserved in the perceiver's memory. But Tolstoy comments that in such case there will be no infection at all, only recollections of some previous infection will take place [13. P. 140].7

Of course, an artist who creates during a considerable period of time cannot always be in a certain emotional state. In order to make the creation infectious, the artist must periodically recreate the feeling which she tries to express in it, but, in time, feelings may fade and become mere recollections of feelings after all. If a writer writes a novel and only one part of which expresses real feelings while others rather communicate faded copies or recollections, according to Tolstoy, these different parts of the novel must infect with different force (some of them perhaps being not infectious at all). 8

But is it impossible for a work to be inspired by one feeling and communicate another due to some cultural or psychological differences between the author and the perceivers and to physical changes which the work came through. Perhaps Tolstoy would challenge artistic values of such works whoever were their authors. But if a person didn't master enough the expressive means she is trying to use, however strong the feeling she is trying to express by these means is, they maybe just incapable to communicate it. This looks rather impossible from Tolstoy's perspective. ${ }^{9}$

Finally, accepting in general an idea of art as a means of communication one may insist that feelings are not the only

\footnotetext{
${ }^{7}$ But this does not mean that there are no more problems with this account. Thus woodblocks and lithographs seem to be an interesting case concerning the infection as a sign of true art. Experiences got from different prints made from the same drawing (let's suppose that it satisfies Tolstoy's criteria for art) may be different. Nevertheless neither the cutter nor the printer might put any feelings of their own into their print works. If these works still may be infectious, as some of them are supposed to be, then the observable differences in experiences wouldn't be fully determined by an original feeling which the artist tried to express, but would depend partially on what the cutter and the printer did however passionlessly.

${ }^{8}$ It is certainly an empirical question, how such works with different emotional background are perceived in real life. Later psychological arguments in favor of Tolstoy's interpretation of such cases were formulated by L. Vygotsky [14. PP. 296-298].

${ }^{9}$ But note that Tolstoy himself rewrote many times his "War and World" in attempts to reach a maximal expressivity: what if he was limited in time as many other authors were? Could he do what he wanted from the first or the second attempt? The role of the form in a work of art is still an important question in philosophy of art. Thus such aesthetic movements and theories as Russian formalism and Vygotsky's psychology of art, influenced by Tolstoy's concept of artistic infection, stressed also an importance of a form of an artwork in its interactions with people.
} 
and perhaps even not the most important content of art: art may communicate thoughts just like words. Moreover, it can be noticed that while a work may be produced without any passion, it is almost impossible to imagine a work without any thought behind it: even by drawing something abstract an artist usually cares about some harmony which becomes the idea communicated by the work when accomplished. But how does one distinguish art from other means of communication? Will there not be too much art in the world, even if we reduce artistic expressions to those which have some specific formal or stylistic features? Perhaps, but who knows a priori how much art is there? According to Tolstoy, many things and events used and produced by people in their everyday life can be emotionally infectious, and, hence, may be considered pieces of art (songs, jokes, decorations etc.). On the other hand, even if we take communication of thoughts as one, the function of art wouldn't contradict perceiving its emotional infectiousness as its crucial feature: the claim that only those expressions of thoughts which are emotionally infectious are artworks looks plausible.

\section{TOLSTOY's ETICISM}

Tolstoy points out two fallacies connected with an idea of art as a means of emotional infection. One consists of treating art as some sort of evil that ought to be prohibited because it may infect people with some feeling against their will; and, often, people count things that corrupt themas art. But it is impossible to realize this prohibition. Another fallacy comes from an identification of art with some kind of pleasure and consists in a requirement to permit any art which gives pleasure. This fallacy Tolstoy considers to be much worse than the first one; but it is extremely common. In order to explain this, he tells us the following story.

According to him, personal understanding of the meaning of one's life generally determines evaluation of certain art (i.e. of what is good and what is bad for him or her in his or her life). The good and the bad, in turn, are determined for him by religion: it gives the meaning and an ideal of life, and sets the criteria of evaluation of human feelings. So, he assumes it was for all nations in all times including first Christians, but massive conversion of pagans to Christianity led to the appearance of another type of Christianity (church Christianity), higher in comparison with the previous religious beliefs of these nations but closer to paganism than the previous Christianity. "Church Christianity made blind faith in Church and its postulates an essence of its doctrine" [13. P. 92]. ${ }^{10}$ In this version of Christianity, the criteria of evaluation of feelings and art had changed relative to original Christian criteria. Still art created within this faith was genuine because artists and poets who had been creating it lived by the same religion and same feelings as the majority of people. At some moment, people belonging to higher circles of society recognized the falsity of Christianity. At this point, they came to the choice: to accept true doctrine of the Christ about the brotherhood of all people and their

\footnotetext{
${ }^{10}$ Tolstoy's negative attitude to the Church is widely known. We will not discuss here how right or wrong he was taking the mass practice as an essence of Church Christianity.
}

equality at the face of God or to deny any religion as such. ${ }^{11}$ Being incapable to do the first thing (because accepting the Christ's doctrine presupposes its realization on life which is very hard) elites returned to a pagan conception of personal pleasure as a meaning of life.

He criticizes the Baumgarten's theory of a triadic unity of Truth, Good and Beauty inspired by Plato. According to Tolstoy, this theory puts together contradicting and even incommensurable notions. For Tolstoy, good is the highest purpose of human life, good and God for him are the same. Beauty, on the other hand, is what we like, because of which it is, as a rule, opposite to the good "since good mostly coincides with the victory over addictions while beauty is the foundation of all our addictions" [13. P. 101]. ${ }^{12}$ And truth is just "a correspondence of an expression to the essence of its subject" and therefore may be or be not an instrument of good [13. P. 102].

These speculations are usually taken as showing Tolstoy's notorious ethics according to which religion, art, science and philosophy are good so far as they serve to a specific and understandable good, but things are not that simple. In fact, there are two types of art for Tolstoy: the religious people's art and art giving pleasure that is the art of higher classes, absolutely inconceivable by simple people and harmful for them. And so it happen that the second one substituted the first. But the substitution, Tolstoy claims, took place only for educated classes, while ordinary people continue to consume and produce their own art. ${ }^{13}$

Talking about the art of educated and usually not religious classes, Tolstoy stresses its socially determined character: only under the condition of intensive labor of workers artists may achieve the perfection they create, produce their refined works, and find the sophisticated audience that values and consumes these works of art. In order to preserve and justify this state of affairs, educated classes create different theories: e.g. those claiming that new art will become available to ordinary people in the future or contrariwise (and this is much more honest) that this is art only for chosen, and, if someone doesn't understand, it's her problem.

According to Tolstoy, identifying the purpose of art with a pleasure of few is also not good for art itself. This way art loses its original endless diversity and deep religious content: "meaning only small circle of people it lost beauty of its form, became pretentious and unclear; and what is more

\footnotetext{
${ }^{11}$ We also will not discuss here Tolstoy's theological views. For the criticism see [10].

${ }^{12}$ What concerns so called spiritual beauty, he goes on, nothing but good is normally understood by this term.

${ }^{13}$ Although elements of corruption penetrate it more and more too [13. P. 108]. Of course considering these speculations we have to keep in mind the gap between lives and cultures of Russian higher and lower classes which took place during Tolstoy's lifetime. Later through the cataclysms of Russian XX's century history the gap was almost eliminated. Therefore the distinction between peoples' art and art for higher classes was mostly substituted by the distinction between elitist art and popular art. The later wasn't the object of Tolstoy's analysis but it obviously doesn't satisfy his criteria of genuine art. An extensive analysis of industrially produced popular art was later given in [3].
} 
important, it ceased to be sincere, became factious and rational" [13. P. 108]. All these for him are signs of a counterfeit art. Further, by quitting being religious, i.e. depicting endless diversity of feelings generated by religious mind, it ceased to be peoples' art, which means an extreme narrowing of the range of feelings expressed by it. "Almost all feelings of people of our circle, - Tolstoy writes, - reduce to three very worthless and simple feelings: pride, lust and melancholy of life" [13. P. 111]. ${ }^{14}$ This narrowness of content goes side-by-side with the pretentiousness and unclearness of the forms of new art. He considers art of highest classes as nothing more than entertainment, but entertainment becomes boring if continuously repeated. That's why it is needed to renew time and again the form of an entertainment. However, the pretentiousness of the form makes such art unconceivable for most people, even for the majority of educated audience, too. But the later trains to see art in new forms without their understanding. Such art loses its main purpose: to be the toll of communication.

So, according to Tolstoy, art in the highest sense of this word must be conceivable by everyone, perhaps with the exclusion of some narrow circle of non-religious people but not vice versa. Of course one may ask: what if the majority of people were not religious? Would art conceivable by them be genuine? Most likely Tolstoy's answer would be "No" because he would amount the loss of religious feelings to the extreme narrowing of people's emotional sphere, and, as a result, to counterfeit art propagating mechanisms. Nevertheless, the possible non-religiousness of the majority of people doesn't prevent considering conceivability by a majority as a criterion of genuine art. Aesthetic and moral values of the majority, depending on the conditions of their life, may be very low though: such that only most worthless feelings would be conceivable by them. Tolstoy is known for his disposition to idealize ordinary people, but he would probably agree that under certain pressure from the state people may degrade. In this case, the taste of majority would most likely cease to be the criteria of genuine art.

But perception of art may change in time, and some pieces of people's art may become perceived as pieces of elitist or popular art. Do they lose their original value? Perhaps Tolstoy's answer should be "Yes".

\section{REAL AND COUNTERFEIT ART}

Tolstoy's extreme rigor concerning art forced many following thinkers to deny the proposed identification of elitist art with bad or counterfeit art. The most sticking example of this reaction is formalism in art, but, for Tolstoy, it is essential that the formation of elitist art leads to the substitution of genuine art with fakes. Since such art is required to depict only that which pleases the feelings of the members of certain classes. In order to achieve constant entertainment for consumers, his art needs to be inventive. To simplify the process of creation of artworks at the face of growing demand artists invented a number of techniques,

14 Tolstoy may obviously be reproached in exaggerating the narrowness of interests of members of his own class. However it seems generally true that the wider the range of interests and points of view which an art can express the higher its expressive potential ceteris paribus. they could produce things similar to art with. These techniques are: borrowing, imitation, surprisingness and interestingness [13. P. 139]. Borrowing is reproduction of certain features or even whole plots of previous artworks when they are changed to the effect of looking as somewhat new with some minor additions [13. P. 140]. Imitation consists in transmitting the details of what is being described or depicted aimed at maximal correspondence of the image to the original. Surprisingness is an intensive impact on senses and is created mainly by contrasts when opposite traits adjoin: terrible and tender, loud and quiet etc. Another way to affect a consumer of art is to depict by means of one art something which is normally depicted by another means. And yet each kind of art has its own additional tools of producing such effects [13. PP. 142-143]. Interestingness satisfies "mind's interest attached to the piece of art". It is reached by an entangled plot, documentary and complexity of expressive techniques when an artwork becomes a rebus one needs to decipher [13. P. 143]. All these tools substitute real art in the end, which purpose is to express and transmit through the unity of form and content a feeling experienced by an artist with something else. He finds examples of such substitution in many classical pieces of art as well as in many works of his own which artistic value his thus rejects.

All of these traits may also characterize the art conceivable by a majority of people and expressing their most intrinsic feelings. The need in techniques which would simplify the art production emerges from the growth of demand and, therefore, has economic foundations. This certainly hints that the conceivability by a majority may not be an independent criterion of real art. Another thing is expressiveness: if an artist expressed in a work his or her feeling or emotional state, other people may understand and experience then it seems reasonable to classify this work as real art even if it was created with some techniques purported to increase its attraction by making it surprising, interesting etc.

Tolstoy claims that there are three social institutes facilitating the popularity of counterfeit art, all created in order to control art by producing artists of certain required types. These are professional artists, art criticism and art school [13. P. 150]. Professional artists are dominant when artists have to produce pleasures for rich people and destroys the main property of art: its sincerity. An artist who needs to earn money for life by his or her art has to invent subjects of his or her works, and depends upon an audience. This stimulates the production of counterfeits.

Art criticism consists in evaluation of art by experts who are for Tolstoy "perverted and at the same time selfconfident people" [13. P. 151]. He believes that since an artwork conveys feeling its construing words "proves only that the construing one is unable to be infected by art" [13. P. $152]$. The genuineness of nationwide art is based, according to him, on the religious consciousness; modern art instead focuses on tastes of most educated people, their authority and tradition based on this authority. Authoritative critiques lift credible artists at a pedestal. Listening to critiques' judgments, a young artist begins to imitate the proposed samples and thus produces counterfeit art in turn. If critiques 
begin to praise these imitations, others begin to imitate them, and so on ad infinitum. But this is not all harm done by critiques: "being unable to be infected by art critiques pay main attention and praise rational, fictional works, and propose them as samples of art" [13. P. 153]. In order to justify their attitude, they invent certain theories which are subdued due to their pretensions for universality not by just anyone, but also real artists who thus have to violate their nature.

But the most harmful institution of modern art Tolstoy considers is art school. It is based on the learning on examples, and "teaches to communicate feelings experienced by other artists by manners by which they were communicated by those artists" [13. P. 155]. But art consists of one's own feeling communicated; this art school based on standard samples cannot teach. Schools kill in artists the capacity to produce art, and develop instead the capacity to produce counterfeits.

Tolstoy lists the following conditions for producing the true piece of art: an artist "must stand at the highest level of world perception of that time, experience a feeling and have desire and possibility to communicate it, and additionally have talent in some art" [13. P. 147]. By talent he means first of all technical skills, e.g., to distinguish, remember and convey lines, forms and colors in fine art. But the use of a talent without any feeling would lead, Tolstoy says, at best to the creation of some counterfeit art.

He does not clarify how the level of world perception of an artist must be connected with the experienced feelings which an artwork created by her purports to express. Nor he explains how this highest level of world perception is linked to the religious and moral consciousness. Ex hypothesis all three should correlate, i.e. that the feeling an artist tries to express should be a result of his or her world perception and the later should correspond to the highest moral and religious values and ideals.

Thus, it seems that correspondence to a certain ideal is an important criterion of real art for Tolstoy. The ideal is determined by a religious consciousness of a historical period and society: i.e. by the highest understanding of a meaning of life the society had reached in that period. In this respect Tolstoy shares quiet popular theory of progress of his time, but he counts states of religion rather than science as indications of progress. Alongside this substantive criterion of art, Tolstoy describes a consequential one that is the infectiousness: "The stronger the infection the better is art as art, not to mention the content, i.e. regardless the value of feelings which it communicates" [13. P. 180]. Infectiousness depends on the specificity of a communicated feeling, clarity of its communication and sincerity of an artist, which is the artist's inner prompting to express this feeling. The sincerity Tolstoy counts as the most important condition. ${ }^{15}$

Therefore, those who think that the value of art for Tolstoy is determined by its interaction with ethical ideal are

\footnotetext{
${ }^{15}$ It is worth mentioning that sincerity here is not identical to the force of feeling: one may have very strong feeling but no internal need to express it, and vice a versa.
}

only partially right: art's aesthetic qualities cannot be reduced to its ethical or religious content.

Taking into account how widespread different forms of art are, there is no surprise in that art often looks morally indifferent and, sometimes, even amoral. If the work satisfies the Tolstoy's conditions of real art, it is first of all a mean of communication of certain feeling, and this feeling is intentional, as, for instance, a fear of death, then relative to its force (how much it affects people) it will be more or less effective tool for promoting the value that is an intentional subject of this feeling. ${ }^{16}$ Tolstoy's idea of art resembles in this respect sociological theories treating artworks as first of all tools for promoting different values, often moral and political, functioning within a special set of institutes or practices. ${ }^{17}$ From this point of view, Tolstoy describes one version of optimal conditions of art's capability to play this social role. Certainly for him, what values art transmits has crucial importance; his ethical rigorism distinguishes him substantially from more relativistic sociologists of art.

\section{Role OF AEsthetics In MORAL JUdGMENTS}

Along with contributions to the promotion of ethical values made by art, one also can observe the opposite influence: aesthetical preferences may influence moral evaluations and decisions. Thus, looking at a picture where some ugly person is doing something bad, a normal observer may feel outrageous not only by the bad thing depicted, but also by the fact that such an ugly person is doing this thing. The same evil depicted or described as done by some beautiful actor may elicit much less indignation or readiness to do something about it. Of course, evil or injustice made by beautiful or charming people does not cease to be seen as evil or unjustified by normal observers, but they more often cause sympathy in spite of what they did wrong. It is easier for them to justify their bad action to other people. Doesn't this mean that people are often (and perhaps even normally, i.e. statistically dominantly) interested not only in ethical, but also in aesthetical background of moral judgments? While ugliness of an agent of action may and often do facilitate negative moral judgments (i.e. judging certain things as obviously bad or a person as definitely morally responsible for it), her beauty may and often make us at least restrain from such judgment (or from judging right now). ${ }^{18}$ According to Tolstoy, who defines art not via its relation to beauty, only sincere creativity motivated by a religious consciousness may serve good after all. But there is also

\footnotetext{
${ }^{16}$ Thus, fear of death corresponds to the idea of death as something fearsome: by communicating this feeling the one communicates this idea too. The fearsomeness is normally interpreted as a sign of a negative value relative to an object opposite to the scaring one. Life is normally perceived as opposite to death: so fear of death normally communicates the information that life is better than death.

${ }^{17}$ See e.g. an exposition of art as a social system in [9].

${ }^{18}$ Of course it does not follow from the fact that ugliness is sometimes perceived as a sign of wickedness that such perceptions are right. We are free to consider such reactions as simply wrong, based on a fallacy. But here we don't discuss the value of this practice, though since it was preserved in spite of a great deal of persuasive work made by the theory that there is no essential connection between aesthetic effects which objects produces in ourselves and their ethical features, it should at least be taken seriously.
} 
another model of relations between aesthetic and ethic values in Russian philosophy according to which beauty has a decisive moral significance. This model is represented by aesthetic views of K. Leontiev.

Leontiev seems to be Tolstoy's antipode in concerns of relations between art and morality. Both are worried very much by contradictions between these two kinds of human activity, but while Tolstoy took the side of morality, Leontiev chose the side of art.

"Aesthetism" may be seen as the main feature of Leontiev's worldview. Aesthetism is not abstract like a meditative aesthetism of romantics, it is willing and aimed at an actualization of beautiful or at least prevention (when possible) the appearance of ugly. He believes in particular aesthetical ideal and is ready to act for its sake and against whatever opposes it. His aesthetic views are scattered over different works mainly dedicated to the investigation of historical development laws and political movements of his time. ${ }^{19}$ Leontiev belongs to Russian Slavophils and borrows many of his social ideas from N. Danilevsky, first of all his denial of universal human history and culture, and the theory of cultural-historical types developing independently just like biological organisms [4. PP. 122-123]. ${ }^{20}$

Aesthetically, Leontiev tends to see in history as much diversity merged in a firm unity as possible. He takes the idea of evolution right from biology believing that in society, like in nature, evolution consists of a steady transformation of simpler forms into more complex forms alongside their individuation either from an environment or from similar and akin phenomena. Evolution presupposes both the growth of internal complexity and diversity of constituents along with the strengthening of unity. The highest point of such development is the greatest complexity merged in an internal despotic unity. Describing the law of any evolution, he distinguished three elements of this process: initial simplicity, flourishing unity and complexity and secondary mixing simplification foretelling the death of the organism. Not only countries, but cultures and their specific areas, e.g. art, literature and philosophy, subdue to this law according to Leontiev [7. P. 382].

Speaking of an object of evolution in general, Leontiev uses an Aristotelian notion of form he defines as "a despotism of internal idea that doesn't let matter to disperse" [7. P. 383]. Form of any kind - organic, political, artistic (style) - is something initial to prevent phenomenon from dying. The despotism of form is essential for any cultural phenomenon and any creativity as well. In our world, beauty, he believes, is always emerged and preserved by way of violence of an artist over the matter, himself or herself and the content which s/he tries to input in the form.

Leontiev is an ethical relativist; he doesn't see reasons for universal morality or at least for unprejudiced moral evaluations. Beauty, on the contrary, has universal

\footnotetext{
${ }^{19}$ The most notable among these works is "Bisantism and Slavity" [7].

${ }^{20}$ An analogy between society and biological organism was quite popular in the second half of XIX century; in XX century it will find its most famous realization in structural functionalism by Talcott Parsons.
}

significance for him. He argues that it is as universal as physics; but unlike the latter aesthetics often contradicts to morality as well as to common sense. One may react in different ways to the antagonism between ethics and aesthetics: hate aesthetics or scorn morality, but Leontiev considers both of these reactions false because they deny what is obviously valuable. He sees a better solution in religion, illustrating this paradoxical thesis (considering his own relativism concerning religion as well as morality) by an example of duel. He claims that duels are beautiful and refuses to participate in it because of the fear of death being ugly and pathetic. A brave man who rejects to take part in duel after an internal struggle because of his fear of God produces a high and touching impression, hence an aesthetic one. Therefore, religion becomes closer to aesthetics than to morality according to Leontiev. He is ready to love a victory of a spiritual feeling over an aesthetic one but is disposed to be outraged by a defeat of the later by reasons of utilitarian ethics [8. P. 79].

Leontiev shares belief almost common among Russian thinkers of that time that life aesthetics is more important than art aesthetics: the second depends on the first. If there is an intensive struggle of religious with aesthetic (also demonic in Leontiev's terms), brilliant reflections of this struggle will come. The lower the presence of mystical powers in life, the less valuable artistic reflections of this life are. On the other hand, the more diversity in unity life contains, the bigger the place for moral corrections and replenishment of the diversity. The realization of common welfare, he thinks, would be not only aesthetically disgusting but would also kill morality [8. PP. 79-80].

Analyzing the examples Leontiev depends on his personal sense of beauty: to see the beauty in duels, one has to look at them from a particular point of view. The universality of such evaluations is doubtful. Even if we preserve the proposed coordinates, we can see aesthetic attraction not only in religious spirit or consciousness victory over public opinions, including aesthetic evaluation of what's going on, but also in the moral duty victory over reasons of practical utility, including those motivated by aesthetic opinions of others. It seems that speaking about morality, Leontiev sometimes means moral attitudes in general and sometimes a certain system of values he also identifies with utilitarian ethics. Taking this ambiguity of his terminology into account, Leontiev's idea becomes less paradoxical. Utility is determined by situation demands of utilitarian ethics, and they are not universal. Their victory over demands of aesthetics, proposed to have more universal meaning, shouldn't count as right. Meanwhile, the triumph of the spirit preserving adherence to some higher values over aesthetics is itself aesthetically attractive. ${ }^{21}$ Also it becomes easier to understand how the role of religion as an arbiter in a dispute between ethics and aesthetics corresponds to the diversity of religious forms within this theory. Indeed, Leontiev judges from the Orthodox Christian point of view.

\footnotetext{
${ }^{21}$ Compare, e.g: [2. PP. 1122b6-7]. Of course the hypothesis that norms of aesthetics are universal or more universal than those of ethics is itself a matter of a further philosophical discussion. Leontiev follows a naturalistic approach here according to which aesthetics has natural genesis.
} 
If we accept that in abstraction from the content of a religious faith, the very victory of a religious feeling over the practical and utilitarian, similar reasons are beautiful. We should agree that, in spite of the diversity of religions, they all can play the role in question.

\section{CONCLUSION}

We analyzed two very different perspectives on the relation between art and morality, one of which is much better known than the other. We saw that Tolstoy's views, in spite of his aestheticism, are consistent with the existence of different forms of interaction between art and morality, only one of he explicitly prefers. Nevertheless, art may be amoral if it sincerely communicates something bad. Leontiev, in spite of moral relativism claims after all that the very commitment to moral or religious, values a universal significance due to its aesthetic attractiveness. Contents of these values may be different, though. Therefore, both agree that art is not determined by some certain morality, but its significance depends on which ethical values it promotes.

\section{REFERENCES}

[1] Aristotle, Poetics, trans. R. Janko, Indianapolis, Hackett Publishing Company, 1987.

[2] Aristotle, Nicomachean Ethics, Indianapolis, IN: Hackett, 1985.

[3] V. Benjamin (1935), "Das Kunstwerkim Zeitalter seiner technischen Reproduzierbarkeit", V. Benjamin, Gesammelte Schriften, 1968, vol. 1, pp. 431-508.

[4] N. J. Danilevsky, Russia and Europe, Moscow, 1991.

[5] I. Kant, Groundwork of the Metaphysics of Morals, I. Kant, Collected Works in 6 volumes, v. 4, Moscow, Thought, 1965, pp. 219-310.

[6] I. Kant, Critique of Judgment, I. Kant, Collected Works in 6 volumes, v. 5, Moscow, Thought, 1966, pp. 161-530.

[7] K. N. Leontiev, Bisantism and Slavity, K. N. Leontiev, Complete Collection of Works and Letters, v. 7, book 1, Saint-Petersburg, 2005, pp. 300-443.

[8] K. N. Leontiev, "Fathers' Succession: K. Leontiev and I. Fudel: Letters, Essays, Reminiscences", K. N. Leontiev, Attachment to Complete Collection of Works and Letters, Saint-Petersburg, 2012.

[9] N. Luhman, Art as a Social System, Stanford UP., 2000.

[10] J. L. Oreckhanov, A. V. Posternak, "L. N. Tolstoy, F. M. Dostoevsky, and K. N. Leontiev: Sense and Value of Dispute on 'Pink Christianity'", Yaroslavl Pedagogical Bulletin № 3, 2011, v. 1, pp. 34 $-40$.

[11] Plato (c. 380-367 BC) Republic, Cambridge: Cambridge University Press, 1963.

[12] M. Tanner, "Art and Morality", Routledge Encyclopedia of Philosophy, Version 1.1, London and New York: Routledge, 1999.

[13] L.N. Tolstoy, (1896) What is Art? L. N. Tolstoy, Collected Works in 20 volumes, v. 15, Moscow, 1964, pp. 44-242.

[14] L.S. Vygotsky, (1925) The Psychology of Art, Moscow, "Labyrinth", 1997. 